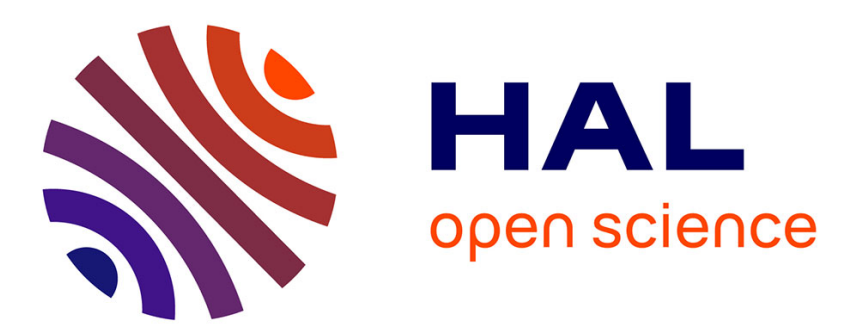

\title{
Reentrant nematic and columnar phases in disc-like liquid crystals at atmospheric pressure
}

\author{
Nguyen Huu Tinh, J. Malthête, C. Destrade
}

\section{To cite this version:}

Nguyen Huu Tinh, J. Malthête, C. Destrade. Reentrant nematic and columnar phases in disc-like liquid crystals at atmospheric pressure. Journal de Physique Lettres, 1981, 42 (18), pp.417-419. 10.1051/jphyslet:019810042018041700 . jpa-00231962

\section{HAL Id: jpa-00231962 https://hal.science/jpa-00231962}

Submitted on 1 Jan 1981

HAL is a multi-disciplinary open access archive for the deposit and dissemination of scientific research documents, whether they are published or not. The documents may come from teaching and research institutions in France or abroad, or from public or private research centers.
L'archive ouverte pluridisciplinaire HAL, est destinée au dépôt et à la diffusion de documents scientifiques de niveau recherche, publiés ou non, émanant des établissements d'enseignement et de recherche français ou étrangers, des laboratoires publics ou privés. 


\title{
Reentrant nematic and columnar phases in disc-like liquid crystals at atmospheric pressure (*)
}

\author{
Nguyen Huu Tinh, J. Malthête $\left({ }^{* *}\right)$ and C. Destrade \\ Centre de Recherche Paul-Pascal, Domaine Universitaire, 33405 Talence Cedex, France \\ (**) Laboratoire de Chimie des Interactions Moléculaires, Collège de France, 75231 Paris Cedex, France
}

(Reçu le 9 juin 1981, accepté le 3 août 1981)

\begin{abstract}
Résumé. - Un composé discoïde présente, pour la première fois, deux mésophases "rentrantes » à la pression atmosphérique : une phase nématique $N_{D}$ et une phase en colonne $D_{r}$
\end{abstract}

Abstract. - We describe the first example of reentrant $N_{D}$ nematic and $D_{r}$ columnar mesophases at atmospheric pressure in a pure disc-like compound.

1. Introduction. - Reentrant mesomorphism is now a well known phenomenon. It was discovered in the last years in rod-like liquid crystals and consists, for example, of the reappearance, after a smectic $A$ phase $\left(\mathrm{S}_{\mathrm{A}}\right)$, of another nematic phase $(\mathrm{N})$ by lowering the temperature or by increasing the pressure.

P. E. Cladis observed this non-classical behaviour first in a binary mixture at atmospheric pressure $[1,2]$ and then, for a pure substance at high pressure $[3,4]$. At last, it was observed by F. Hardouin et al. $[5,6]$ with a pure substance at atmospheric pressure in the case of 4-n-octyloxybenzoyloxy-4'-cyanostilbene 1 $\left(\mathrm{X}=-\mathrm{CH}=\mathrm{CH}-, \mathrm{R}=\mathrm{n}-\mathrm{C}_{8} \mathrm{H}_{17} \mathrm{O}-\right)$, which offered two reentrant phases $\left(\bar{K}\left[\mathrm{~S}_{\mathrm{A}}\right] \mathrm{NS}_{\mathrm{A}} \mathrm{NI} ; \mathrm{K}\right.$ : crystal, $I$ : isotropic).

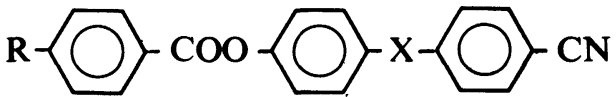

with

$\mathrm{R}=\mathrm{C}_{n} \mathrm{H}_{2 n+1}-, \quad \mathrm{C}_{n} \mathrm{H}_{2 n+1} \mathrm{O}-, \quad \mathrm{C}_{n} \mathrm{H}_{2 n+1} \mathrm{COO}-$ and

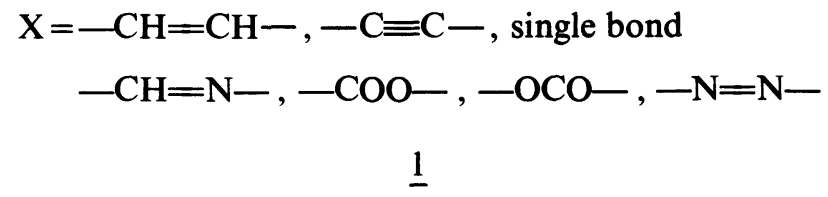

(*) This work has been financially supported by the french D.R.E.T. (contrat $n^{\circ} 80 / 227$ ).
Since this time, many other "reentrant" homologous series have been synthesized; they consist of three phenyl ring compounds 1 with a para strong dipolar cyano substituent [7-16].

In the case of disc-like liquid crystals, the existence of the reentrant phenomenon was suggested in the end of 1979 [17]. This hypothesis originated from the great symmetry analogies between the arrangements of rod-like and disc-like liquid crystals : the columnar and $N_{D}$ nematic mesophases are respectively similar to smectic and nematic ones.

We described the first examples of a nematic phase observed from disc-like molecules in series of hexaalkoxy or hexaalkylbenzoates of triphenylene $[18,19]$. We called it a $N_{D}$ nematic phase in the "normal " sequence : $\mathrm{KD}_{\mathrm{r}} \mathrm{N}_{\mathrm{D}} \mathrm{I}\left(\mathrm{D}_{\mathrm{r}}\right.$ : rectangular columnar phase) - «normal » because the fluid $N_{D}$ nematic phase was observed while increasing temperature $\left(168{ }^{\circ} \mathrm{C}\right.$ at least) after a viscous columnar phase.

But, in the series of truxene hexaalkanoates [20,21], we obtained a $\mathrm{N}_{\mathrm{D}}$ nematic phase at low temperature (about $60^{\circ} \mathrm{C}$ ) in an inverse sequence :K $N_{D} D_{r} D_{h} I$ ( $D_{h}$ : hexagonal columnar phase). The $\mathrm{N}_{\mathrm{D}}$ fluid phase was now at lower temperature than the columnar phases.

Despite the fact that this new sequence was not an actual reentrant phenomenon, we thought we had there something similar. In fact, the study of highly purified hexaalkanoates of truxene with very long chains provided us the required phenomenon : a hexagonal reentrant columnar phase with the sequence $K\left(D_{h}\right) N_{D} D_{r} D_{h}$ I [22].

If it is noted that benzoates of triphenylene exhibit a 
$\mathrm{N}_{\mathrm{D}}$ nematic phase at high temperature and truxene derivatives at low temperature, it is easy to understand why we tried to build up benzoates of truxene with the hope to obtain a reentrant $N_{D}$ nematic phase.

We present here preliminary results : 2,3,7,8,12,13hexa-(4-n-undecyloxybenzoyloxy) truxene $\underline{2}$ exhibits, at one and the same time !, reentrant $\mathrm{N}_{\mathrm{D}}$ nematic and $\mathrm{D}_{\mathrm{r}}$ columnar phases at atmospheric pressure : $K D_{r} N_{D} D_{r} N_{D} I$. This sequence is analogous with the well known tetramorphism in rod-like liquid crystals $\left(\mathrm{K} \mathrm{S}_{\mathrm{A}} \mathrm{N} \mathrm{S}_{\mathrm{A}} \mathrm{N} \mathrm{I}\right)$.

2. Results. - The compound 2 was prepared by reaction of the 4-n-undecyloxybenzoyl chloride with $2,3,7,8,12,13$-hexahydroxytruxene in anhydrous pyridine [20]. The purity of the sample was checked by elemental analysis and thin layer chromatography. Transition temperatures were determined using a DSC (Dupont 990). The textures were observed with polarizing microscope equipped with a heating and cooling stage (Mettler FP5).

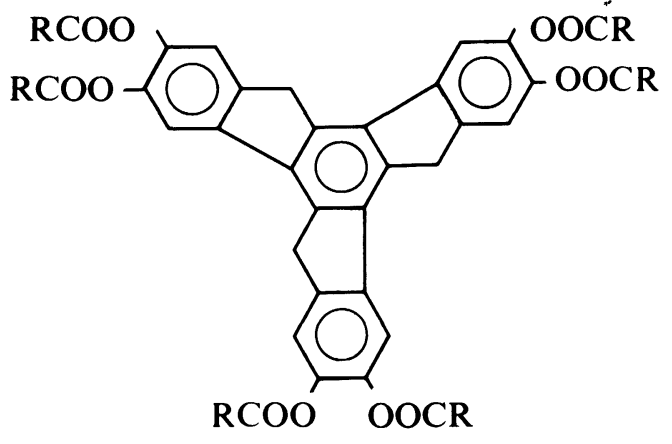

with : $\mathrm{R}=\mathrm{C}_{11} \mathrm{H}_{23} \mathrm{O}-\underbrace{\longrightarrow}_{2}$

2 offers the following sequence with the two reentrant mesophases $D_{r}$ and $N_{D}$ :

$$
\begin{array}{lllllll}
\text { K } 90 & D_{\mathrm{r}} 137 & \mathrm{~N}_{\mathrm{D}} & 171 & \mathrm{D}_{\mathrm{r}} 284 & \mathrm{~N}_{\mathrm{D}} 297 \text { I. }
\end{array}
$$

The corresponding optical textures are given in figures $1 a$ through $1 d$. At high temperature (about $290^{\circ} \mathrm{C}$ ), we can observe the $\mathrm{N}_{\mathrm{D}}$ nematic phase with a thread-like or marbled texture. Below this $\mathrm{N}_{\mathrm{D}}$ phase, the $D_{r}$ columnar phase appears with a fan-shaped texture. On further cooling, another classical threadlike texture, with disclination lines $\left(s: \pm \frac{1}{2}\right.$ and \pm 1$)$, is observed, followed by a fan shaped phase.

The identification of these two $\mathrm{N}_{D}$ nematic phases is immediate in the isobaric phase diagram (Fig. 2) between $\underline{2}$ and 2,3,6,7,10,11-hexa-(4-n-decyloxybenzoyloxy) triphenylene 3 [19] (K $\left.142 \mathrm{D}_{\mathrm{r}} 191 \mathrm{~N}_{\mathrm{D}} 212 \mathrm{I}\right)$. The diagram proves the identity of the two $N_{D}$ nematic phases of $\underline{2}$ with the $N_{D}$ phase of $\underline{3}$ : an uninterrupted domain exists. Moreover, the $\mathrm{D}_{\mathrm{r}}$ columnar phase at low temperature - of $\underline{2}$ is miscible with the $D_{r}$ phase of $\underline{3}$

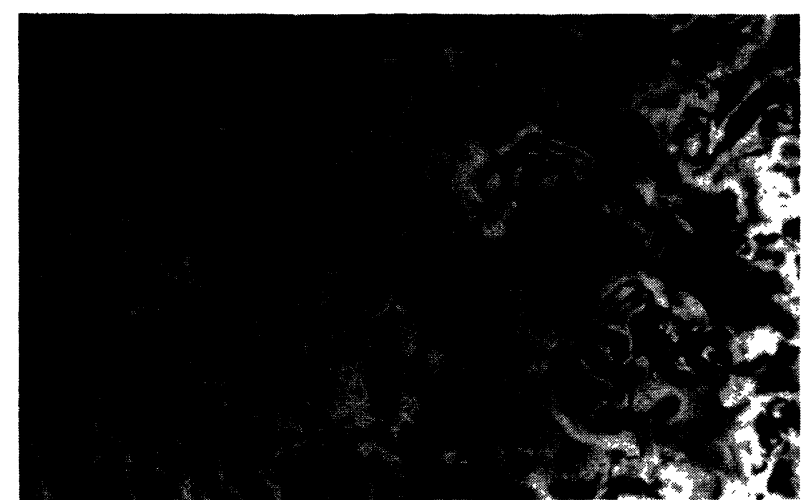

a)

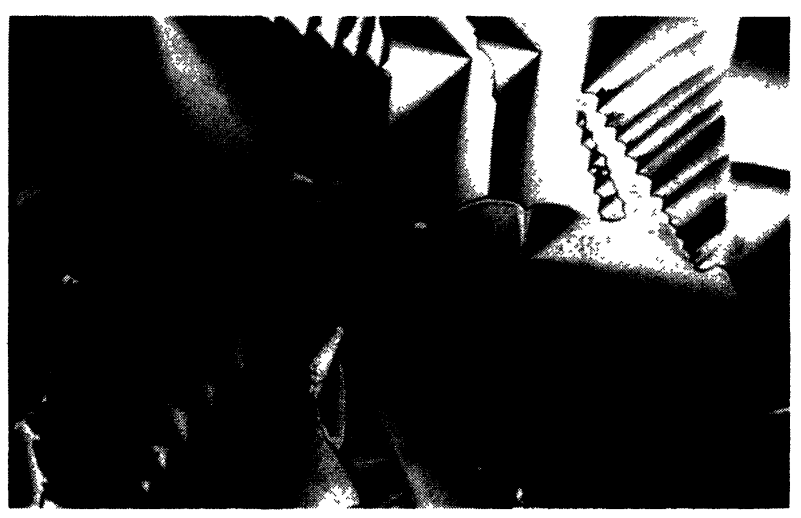

b)

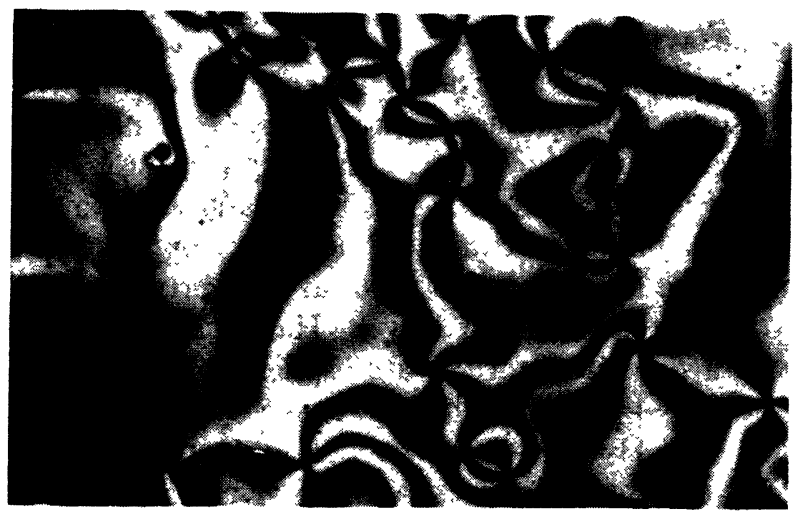

c)

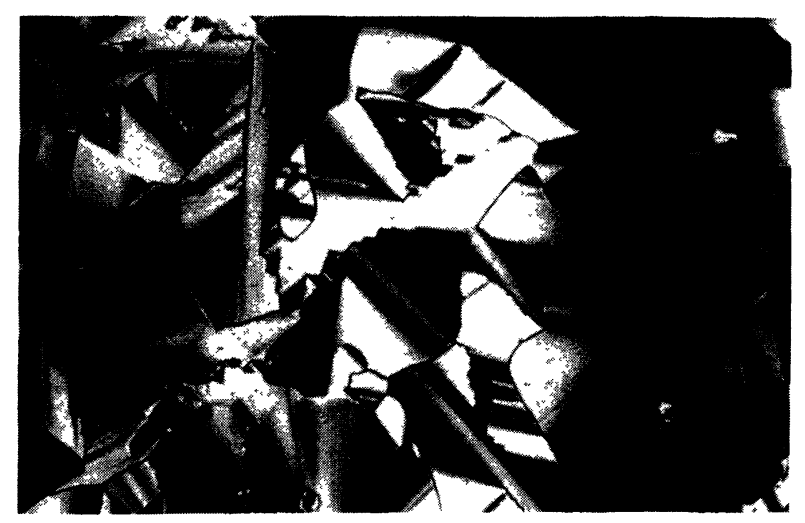

d)

Fig. 1. - Optical textures of the compound 2 : a) $\mathrm{N}_{\mathrm{D}}$ nematic phase at $290^{\circ} \mathrm{C}$; b) $\mathrm{D}_{\mathrm{r}}$ columnar phase at $175^{\circ} \overline{\mathrm{C}}$; c) $\mathrm{N}_{\mathrm{D}}$ reentrant nematic phase at $\left.145^{\circ} \mathrm{C} ; d\right) \mathrm{D}_{\mathrm{r}}$ reentrant columnar phase at $130^{\circ} \mathrm{C}$. 


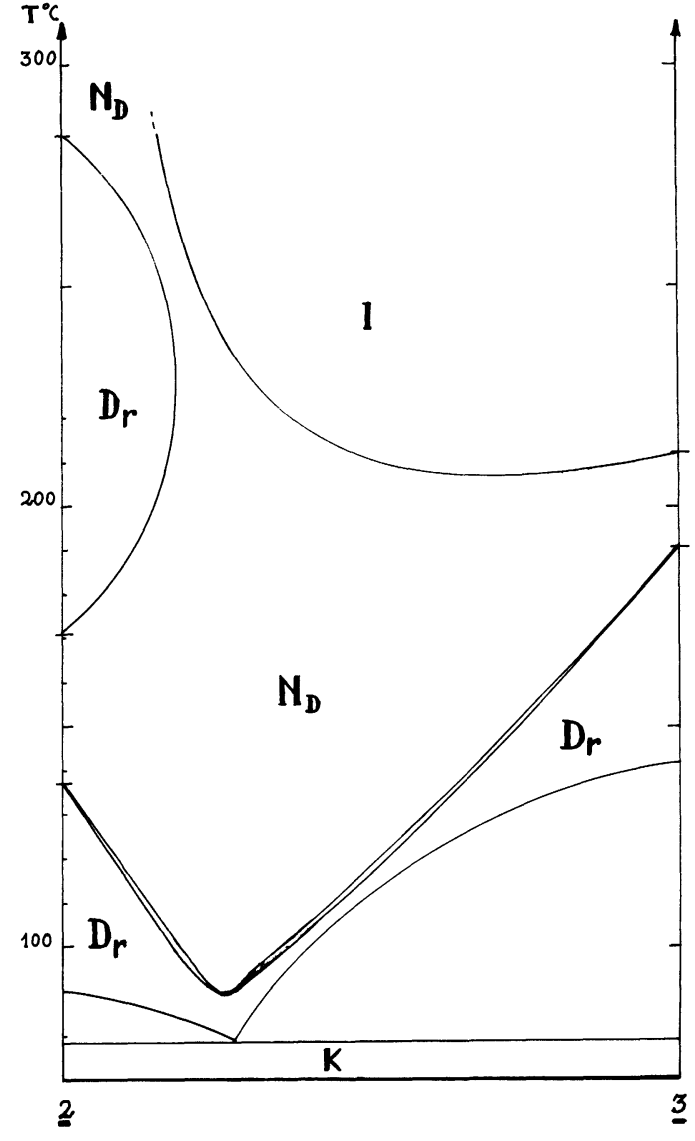

Fig. 2. - Diagram of isobaric state for the mixture of 2 (on left) with $\underline{3}$ (on right).

3. Discussion. - In the case of the "reentrant" $\mathrm{S}_{\mathrm{A}}$ rod-like liquid crystals, it appears necessary to generate molecular "dimers " formed by a partial " head to tail » molecular overlapping. So, the reentrant nematic phase is a consequence of a competition between local smectic $\mathbf{A}$ orders which are different at low and high temperature [23]. This behaviour is observed with molecules involving a strong dipolar end group. Up to now, only para-cyano derivatives 1 exhibit reentrant mesophases [24].

If it is quite difficult to imagine a " head to tail " arrangement in the case of disc-like molecules such as 2, we can suppose that, at low temperature, the conformation of the six carboxyl crown allows the maintenance of cohesion between the truxene cores in "dimers " we imagine present in the crystal (cf. dimers in esters of triphenylene, proved by X-ray diffraction [25]).

Let us emphasize that analogous triphenylene derivatives [17] do not exhibit this phenomenon. This fact shows the prominent part taken by the diameter and the shape of the central aromatic core.

4. Conclusion. - The existence of a reentrant tetramorphism in disc-like molecules once more shows the great analogy between rod-like and disclike liquid crystals. The $\mathrm{N}_{\mathrm{D}}$ nematic, $\mathrm{N}_{\mathrm{D}}^{*}$ cholesteric and six different columnar phases, and reentrant sequences were observed with only about 70 molecules [26]. This remark will surely stimulate new synthetic work in the future.

Acknowledgment. - We thank Professor J. Jacques for stimulating discussions and helpful suggestions.

\section{References}

[1] Cladis, P. E., Phys. Rev. Lett. 35 (1975) 48.

[2] Guillon, D., Cladis, P. E., Stamotoff, J., Phys. Rev. Lett. 41 (1978) 1598.

[3] Cladis, P. E., Bogardus, R. K., Daniels, W. D., Taylor, G. N., Phys. Rev. Lett. 39 (1977) 720.

[4] Cladis, P. E., Bogardus, R. K., Aadsen, D., Phys. Rev. 18 (1978) 2292.

[5] Hardouin, F., Sigaud, G., Achard, M. F., Gasparoux, H., Phys. Lett. 71 A (1979) 317.

[6] Hardouin, F., Sigaud, G., Achard, M. F., Gasparoux, H., Solid State Commun. 30 (1979) 265.

[7] Nguyen Huu Tinh, Sigaud, G., Achard, M. F., Gasparoux, H., Hardouin, F., Proceedings of the 3rd Liq. Cryst. Conf. of Socialist Countries (Hungarian Acad. Sci.) 1979.

[8] Nguyen Huu Tinh, Gasparoux, H., Mol. Cryst. Liq. Cryst. Lett. 49 (1979) 287.

[9] Nguyen Huu Tinh, Pourrere, A., Destrade, C., Mol. Cryst. Liq. Cryst. 62 (1980) 125.

[10] Hardouin, F., Levelut, A. M., Nguyen Huu Tinh, Sigaud, G., Mol. Cryst. Liq. Cryst. Lett. 56 (1979) 35.

[11] Weissflog, W., Pelzl, G., Wiegeleben, A., Demus, D., Mol. Cryst. Liq. Cryst. Lett. 56 (1979) 295.

[12] Nguyen HuU Tinh, ZanN, A., Dubois, J. C., Billard, J., Mol. Cryst. Liq. Cryst. Lett. 56 (1979) 323.

[13] Nguyen Huu Tinh, Joussot-Dubien, M., Destrade, C., Mol. Cryst. Liq. Cryst. Lett. 56 (1979) 257.

[14] Heppke, G., Hopf, R., Kohn, B., Pracfeke, K., 3rd Liq. Cryst. Conf. of Socialist Countries (Hungary) 1979.
[15] Shadashiva, B. K., Int. Liq. Cryst. Conf. Bangalore (1979).

[16] Nguyen Huu Tinh, Destrade, C., Nouv. J. Chimie 5 (1981) 337.

[17] Destrade, C., Bernaud, M. C., Gasparoux, H., Levelut, A. M., Nguyen HuU Tinh, Int. Liq. Cryst. Conf. Bangalore, (Heydon and Son London) 1979.

[18] Nguyen Huu Tinh, Destrade, C., Gasparoux, H., Phys. Lett. 72A (1979) 251.

[19] Nguyen Huu Tinh, Gasparoux, H., Destrade, C., Proc. 8th. Int. Liq. Cryst. Conf. Kyoto (1980).

[20] Destrade, C., Malthete, J., Nguyen HuU Tinh, GaspaROUX, H., Phys. Lett. 78A (1980) 82.

[21] Destrade, C., Malthete, J., Gasparoux, H., Babeau, A., Nguyen HuU Tinh, Proc. 8th. Int. Liq. Cryst. Conf. Kyoto (1980).

[22] Nguyen HuU Tinh, Malthete, J., Destrade, C., Mol. Cryst. Liq. Cryst. Lett. (in press).

[23] Hardouin, F., Levelut, A. M., J. Physique 41 (1980) 41.

[24] Sigaud, G., Nguyen HuU Tinh, Hardoun, F., GaspaRouX, H., Mol. Cryst. Liq. Cryst. (in press).

[25] Cotrait, M., Marsau, P., Destrade, C. and Malthete, J., J. Physique Lett. 40 (1979) L-519.

[26] Destrade, C., Nguyen Huu Tinh, Gasparoux, H., MalThete, J. and Levelut, A. M., Mol. Cryst. Liq. Cryst. (under press). 